Prima: Jurnal Pendidikan Matematika

Vol. 6, No. 1, January 2022, pp. 20-29

P-ISSN: 2579-9827, E-ISSN: 2580-2216

Web: http://jurnal.umt.ac.id/index.php/prima

\title{
ANALYSIS OF STUDENTS' MATHEMATICAL LITERACY ABILITIES IS REVIEWED FROM EMOTIONAL INTELLIGENCE
}

\author{
${ }^{1}$ Retno Andriyani, ${ }^{2}$ Hestu Wilujeng \\ ${ }^{1}$ University Muhammadiyah Tangerang, JL. Perintis Kemerdekaan I/33 Cikokol, Tangerang, Indonesia \\ ${ }^{2}$ Institut Agama Islam Negeri, Jl. Puspita Jaya, Krajan, Pintu, Kec. Jenangan, Kabupaten Ponorogo, Jawa timur, \\ Indonesia \\ e-mail: retnoandriyani61@gmail.com
}

\begin{abstract}
The Abstract should be informative and completely self-explanatory, provide a clear statement of the problem, the proposed approach or solution, and point out major findings and conclusions. The Abstract should be 200 to 250 words in length. The Abstract should be written in the past tense. Standard nomenclature should be used, and abbreviations should be avoided. No literature should be cited. The keyword list provides the opportunity to add keywords used by the indexing and abstracting services, in addition to those already present in the title. Judicious use of keywords may increase the ease with which interested parties can locate our article.
\end{abstract}

Keywords: intellegence, emotional, literacy, mathematical, arithmetic.

\begin{abstract}
Abstrak
Penelitian ini bertujuan untuk mendeskripsikan kemampuan literasi matematis siswa pada aspek komunikasi ditinjau dari kecerdasan emosional dengan materi artimatika sosial. Penelitian ini menggunakan metode kualitatif deskriptif. Subjek penelitian sebanyak 9 siswa yang terdiri dari 3 memiliki kecerdasan emosional rendah, 3 memiliki kecerdasan emosional sedang, dan 3 memiliki kecerdasan emosional tinggi. Data yang dianalisis adalah data hasil tes kemampuan literasi matematis dan hasil wawancara. Hasil analisis data menunjukan 3 siswa kecerdasan emosional tinggi memiliki nilai rata-rata kemampuan 86,7 pada soal aspek komunikasi berkategori sedang pada aspek komunikasi dan berkategori tinggi . 3 siswa kecerdasan emosional sedang memiliki nilai rata-rata kemampuan 96,7 pada soal aspek komunikasi yang menunjukan siswa kecerdasan emosional sedang memiliki kemampuan literasi matematis berkategori sedang pada aspek komunikasi. 3 siswa kecerdasan emosional rendah memiliki nilai rata-rata kemampuan 58,3 pada soal aspek komunikasi dan 65 yang menunjukan siswa kecerdasan emosional rendah memiliki kemampuan literasi matematis berkategori sedang pada aspek komunikasi.
\end{abstract}

Kata Kunci: kecerdasan, emosional, literasi, matematis, aritmatika.

\section{INTRODUCTION}

The skills that must be possessed by students in the 21st century, according to the ministry and culture are: Critical Thinking and Problem Solving (critical thinking and solving problems), Creativity (creativity), Communication Skill (Communication Skills), and Ability to Work Collaboratively (the ability to work together). As defined by PISA 2012, mathematical literacy is the ability to formulate, using mathematics in a variety of contexts. The ability to cover mathematical reasoning and the ability to explain, represent and predict a phenomenon (OECD, 2013)

Mathematical literacy is very important. This is because mathematical literacy emphasizes the ability of students to analyze, argue and communicate ideas effectively on 
solving mathematical problems they encounter, with mastery of mathematical literacy, each individual will reason logically and critically in solving problems faced daily (OECD, 2019).

The reality in the field of mathematical literacy ability of students in Indonesia is still low, this is seen from pisa results from 2000 to 2018 the results obtained by Indonesia are still far from expected. The results of the PISA score for Indonesia can be seen in the following table.

Tabel 1. Sumber : Hasil laporan PISA 2018

\begin{tabular}{cccc}
\hline Year of Study & $\begin{array}{c}\text { Average Score of } \\
\text { Indonesia }\end{array}$ & $\begin{array}{c}\text { International } \\
\text { Average Score }\end{array}$ & $\begin{array}{c}\text { Indonesian Devices } \\
\text { from the Number of } \\
\text { Study Participants }\end{array}$ \\
\hline 2000 & 367 & 500 & 39 dari 41 \\
\hline 2003 & 360 & 500 & 38 dari 40 \\
\hline 2006 & 391 & 500 & 50 dari 56 \\
\hline 2009 & 371 & 500 & 61 dari 65 \\
\hline 2012 & 375 & 500 & 64 dari 65 \\
\hline 2015 & 386 & 500 & 63 dari 69 \\
\hline 2018 & 379 & 500 & 73 dari 79 \\
\hline
\end{tabular}

The results of pisa show that Indonesia is ranked at the bottom. It can be seen that Indonesia's average score is well below the international average score. Based on a researcher's interview with a class VIII math teacher at one of the private junior high schools in Tangerang city in March 2021 the teacher said that during the COVID-19 pandemic learning only went one way from the teacher only, rarely communication of teachers and students about difficulties in learning, learning often only provides materials and assignments, students are only used to working on problems in LKS that are only of a nature. Understanding only, students are not accustomed to being given contextual problems, when given contextual problems in social arithmetic material indicated that: (1) students are not accustomed so difficulty understanding the problem, (2) students are not used to writing down known and asked elements, so that the difficulty in interpreting the problem into the mathematical model. From the above facts researchers suspect that the process of mathematical literacy of students belongs to the low category, especially on the aspect ofcommunication.

According to the OECD (2019) there is a relationship of mathematical processes with communication skills and the ability to design strategies to solve problems. Researchers will 
use the indicator as a reference in looking at students' mathematical communication skills, where the indicators are:

Table 2. Mathematical Literacy Indicators of Communication Aspects

Mathematical Indikator kompetensi Literasi matematis

Literacy

Competence

communication a) Students are able to express mathematical ideas in written, oral and visualize them in the form of simple images.

b) Students are able to connect real objects, drawings and diagrams into mathematical ideas.

The cause of low student mathematical literacy is not only from the lack of practice of contextual problems, students' confidence in their abilities is also a factor that plays a role in realizing the achievement of mathematical literacy. The reality on the ground is that not all students have enough confidence. Feeling unsure of self-ability, shame and minder are obstacles for students in the learning process, so passive students do not dare to express feelings, thoughts and aspirations. In line with Uno's (2016) opinion that self-confidence is a belief and ability to respect themselves that affects behavior, a confident person will feel confident that he is able to do something so that he achieves his goals. According to Daniel Goleman, confidence is one aspect contained in emotional intelligence (Uno, 2016).

While the indicator of emotional intelligence indicator according to Petrides \& Furnham which is summarized in five aspects of emotional intelligence, namely

a. Wellbeing, includes: optimism, happiness, and self-esteem

b. Emotionality, includes: empathy, perception of emotions (self and others), expression of emotions, as well as relationships with others.

c. Self-control, including: emotional regulation, low in conclusion and management of stress.

d. Sociability, includes: management of other people's emotions, assertiveness and social awareness.

e. Auxilary facets, including: adapability and self-motivation. (Sofia, 2016)

One of the decisive factors in achieving learning achievement or success in life is emotional intelligence, this is in line with research conducted by Wiyono, Anggo, and Kadir 
(2019) that there is a positive and significant relationship between emotional intelligence and the achievement of learning mathematics students of class VII of State Junior High School 9 Buru. Goleman said the child's ability to control his emotions will make it easier to concentrate, so that the child's process of receiving and remembering information can increase (Wulan, 2011). Therefore, there is a link between mathematical literacy and emotional intelligence.

\section{Research Methods}

This type of research method is qualitatively descriptive. The research subjects were determined through Purposive sampling and the study was conducted in class IX A SMPS Dharma Students in the 2021/2022 school year. This research data collection technique uses methods of emotional intelligence questionnaires, tests of mathematical literacy skills and interviews. The problem consists of 4 questions. The implementation stage provides emotional intelligence to students of class IX A, then reduces the results of the questionnaire and grouped into three categories, namely: high, medium and low. According to Gay, Mills and Airasian (Alwi, 2012) for the determination of research subjects with descriptive models of research subjects of at least $10 \%$ of the population. Based on experts and the results of emotional intelligence questionnaire selected 3 (three) class students, then in each category of emotional intelligence selected 3 students, then give questions of mathematical literacy skills and conduct interviews to the subject that has been determined.

Table 3. Data Collection Techniques

\begin{tabular}{lccc}
\hline \multicolumn{1}{c}{ Data } & $\begin{array}{c}\text { Data Collection } \\
\text { Techniques }\end{array}$ & Instruments & Data Source \\
\hline $\begin{array}{l}\text { Emotional } \\
\begin{array}{l}\text { Intelligence } \\
\text { Mathematical }\end{array}\end{array}$ & Questionnaire & Angket (29 Items) & Student \\
literacy skills & Test & 5 Questions & Student \\
\hline
\end{tabular}

Based on the results of emotional intelligence questionnaire tests that have been conducted, the determination of the study subjects is based on the average value and standard deviation of the class.

Table 4. Categorization of emotional intelligence

Category Formula Information




\begin{tabular}{cc}
\hline Nilai angket $\geq(\mu+1 \sigma)$ & Tall \\
\hline$(\mu-1 \sigma) \leq$ Nilai angket $<(\mu+$ & Keep \\
$1 \sigma)$ & Low \\
\hline Nilai angket $<(\mu+1 \sigma)$ & \\
\hline
\end{tabular}

(Sofia,2016)

Data analysis in this study is a descriptive technique that is by creating a picture in three ways: Data reduction, presentation of data (data display), and conclusion draw (data conclusion drawing / verification).

\section{RESULTS AND DISCUSSIONS}

Students were given emotional intelligence questionnaires as many as 26 students through google form, the data was then processed and grouped into three categories, namely low, medium and high. The results of categorization of emotional intelligence are presented in the following table:

Table 5. Students' categorization results based on emotional intelligence

\begin{tabular}{|c|c|c|}
\hline Interval & $\begin{array}{l}\text { categories of } \\
\text { emotional intelligence }\end{array}$ & Frekuensi \\
\hline Total score $\geq 159,36$ & High & 3 \\
\hline $\begin{array}{l}100,48 \leq \text { Total score }< \\
159,36\end{array}$ & Medium & 20 \\
\hline \multirow[t]{2}{*}{ Total score $<100,48$} & Low & 3 \\
\hline & Total & 26 \\
\hline
\end{tabular}

Based on the categorization of the results of emotional intelligence questionnaires in table 4 selected 9 students who weresubjects in thisstudy, namely:

\section{Table 6 Research Subjects}

\begin{tabular}{llll}
\hline No & $\begin{array}{c}\text { Subject } \\
\text { Code }\end{array}$ & $\begin{array}{c}\text { Number } \\
\text { of } \\
\text { Scores }\end{array}$ & \multicolumn{1}{c}{ Category } \\
\hline 1. & ST1 & 192 & High \\
\hline 2. & ST2 & 172 & High \\
\hline 3. & ST3 & 162 & High \\
\hline 4. & SS1 & 158 & Medium \\
\hline 5. & SS2 & 111 & Medium \\
\hline
\end{tabular}




\begin{tabular}{llcl}
\hline 6. & SS3 & 115 & Medium \\
\hline 7. & SR1 & 76 & Low \\
\hline 8. & SR2 & 73 & Low \\
\hline 9 & SR3 & 92 & Low \\
\hline
\end{tabular}

Furthermore, the student was given a mathematical literacy test that resulted as follows:

\section{Communication aspects}

High Emotional Intelligence. There is this group in selected 3 students who represent the high group namely ST1, ST2 and ST3. Based on the results of mathematical literacy test scores found that learners with high emotional intelligence theory showed an average of 86.7 and the results of interviews conducted with subjects of high emotional intelligence showed that learners capable of mathematical literacy are in the aspect of communication,learners are able tounderstand and interpret problems in the form of writing, able to present and articulate the process. problem solving but some are not careful in doing calculations so that the results of the conclusion of solving the problem given are not accurate,this can be seen from the following image:
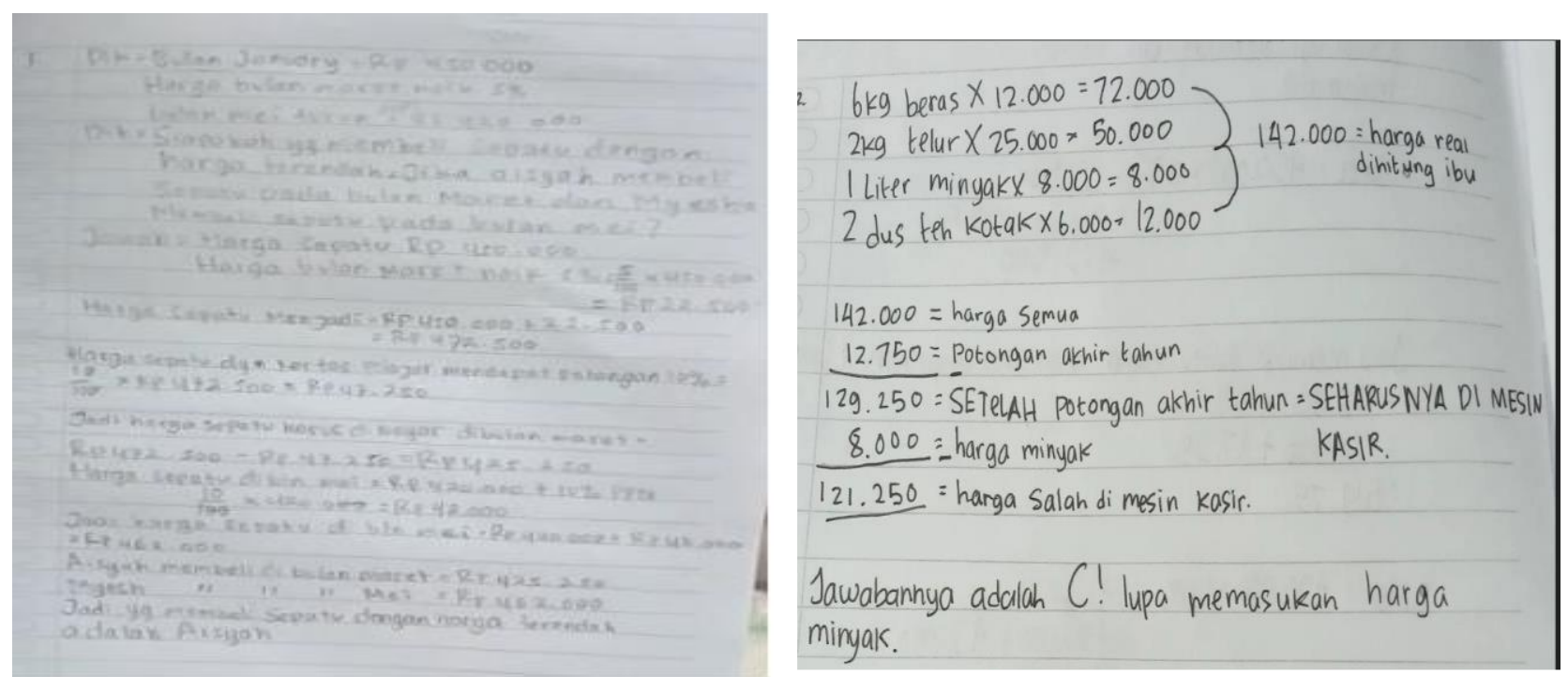

Figure 1. Answers ST1 and ST3

Based on the image of 1 ST1 subject in answering questions 1 and 2 do not write what is known and asked, when interviewed ST1 claimed not to be used in writing the information contained in the problem when given the problem directly to the solution. Based on the work 
on the given problem students high emotional category can design procedures, present the problem solving process in the form of writing in full and perform proper calculation procedures. When interviewed, ST1 and ST3 were able to verbally relay the answers they worked on. In answering question number 1 subjects ST1, ST2 and ST3 are able to write the conclusion of the problem solving but only ST3 writes the conclusion of the problem solving correctly, ST1 has done the calculations precisely but not thoroughly in giving conclusions seen in the subject ST1 number 1.

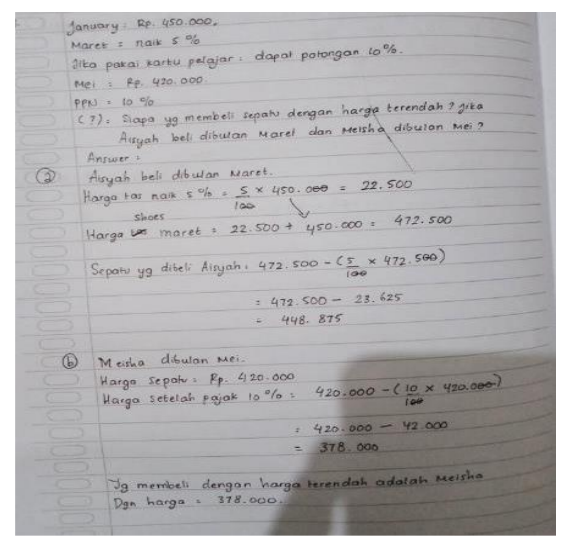

Figure 2. ST 2 results

In answering the subject question ST1, ST2 and ST3 are able to write the conclusion of the problem solving but only ST3 writes the conclusion of the problem solution correctly. ST1 has done the calculations precisely but not thoroughly in providing conclusions Based on the findings of the study above students with high emotional intelligence can be concluded to have moderate communication skills, this is in the opinion of Tri tasyanti, wardono and Rochmad (2018) that students with high levels of emotional intelligence for the communication component in the moderate group because they are able to change the problems that are There is a form of modeling but there is an incomplete definition, causing confusion in the solution of the problem.

Emotional Intelligence Medium. In the emotional group, 3 subjects were selected, namely SS1, SS2, SS3. Based on the results of mathematical literacy ability values found that learners with the theory of emotional intelligence are showing an average of 96.7 and the results of interviews conducted with emotional intelligence subjects are showing that students are high in the communication aspect, learners are able to understand and interpret problems in written and oral form, able to present and Articulate the problem-solving process with appropriate results, and be able to interpret solutions to contextual problems by writing down the conclusions of problem solving. In answering the question do not write down in full what is known and asked in the problem in the form of writing but the subject can explain Prima: Jurnal Pendidikan Matematika Vol. 6, No. 1, January 2022, 20-29 
when interviewed. This is seen in one of the answers of the subject of SS1 number 1.
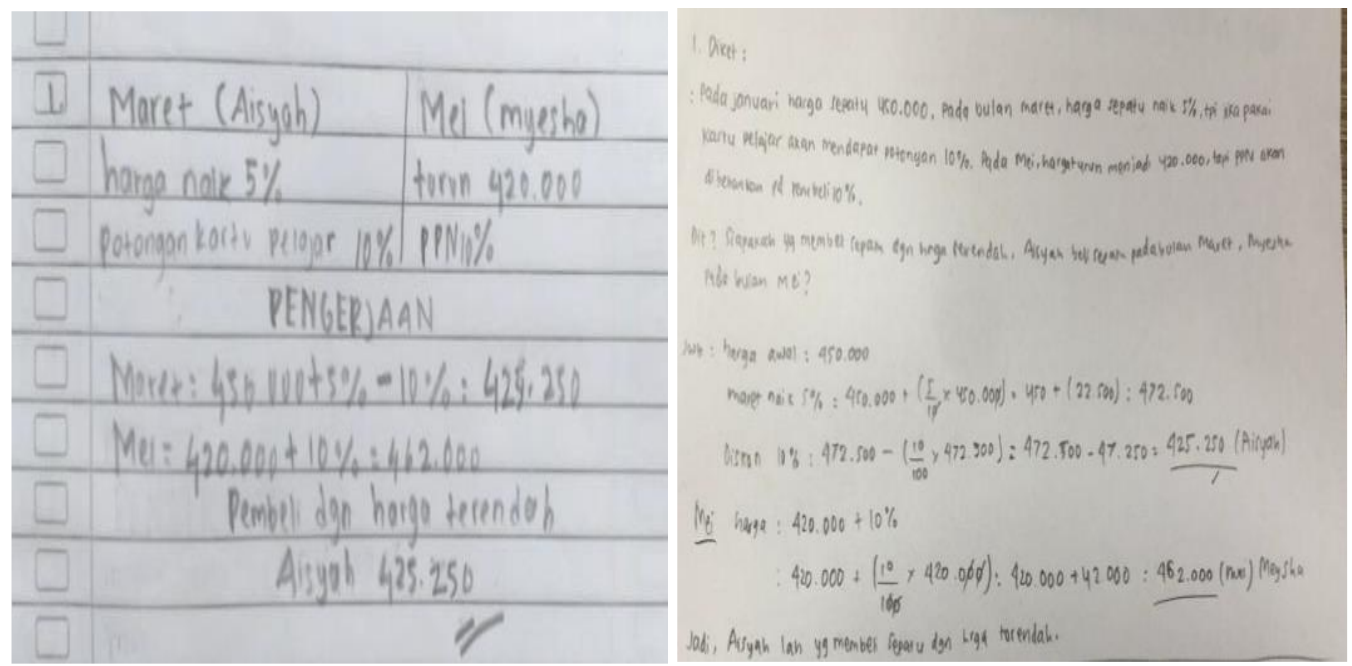

\section{Figure 3. SSI and SS2 Answers}

The subject of SS2 writes in full what is known and asked in the matter in written form.

The subject of SS2 can explain when interviewed on this aspect SSI and SS2 can understand and interpret a problem situation into mathematical ideas in the form of writing or drawings, designprocedures, present and articulate the problem solving process of subjects SS1, SS2 and SS3 can design procedures, present the problem solving process in complete writing form and perform proper calculation procedures. When interviewed, the three subjects were able to convey verbally the answers they were working on, this wasnot seen from figure 4.

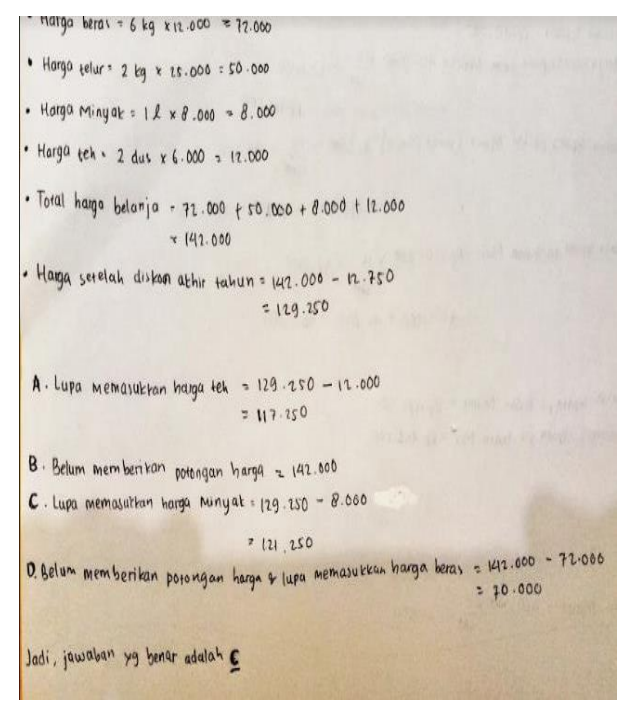

Figure 4. SS3 response results 
Subjek SS3 has provided a correct solution process, but there is a fallacy in interpreting mathematical results into real-world contexts or not being careful in providing conclusions in problem solving. This is in line with the results of research conducted by Tri tasyanti, wardono and Rochmad (2018) that students with emotional intelligence levels are less thorough so that the achievement of indicators in students with emotional intelligence is not yet maximal.

Low Emotional Intelligence. Based on the results of mathematical literacy ability values found that learners with low emotional intelligence theory showed an average of 58.3 and the results of interviews conducted with low emotional intelligence subjects showed that students were in the communication aspect, learners were able to understand and interpret problems in writing form, were able to present and articulate the problem-solving process but There are those who are not careful in doing calculations so that the results of the conclusion of solving the problem given are not accurate.

In understanding and interpreting a problem situation into mathematical ideas in the form of writing or drawing sr1 subjects do not write in full what is known and asked in the problem in written form and is less clear in explaining when interviewed. The subject of SR2 writes in full what is known and asked in the problem in written form and when interviewed is able to explain. This is seen in the answer of the subject SR2 It is seen in figure 5.
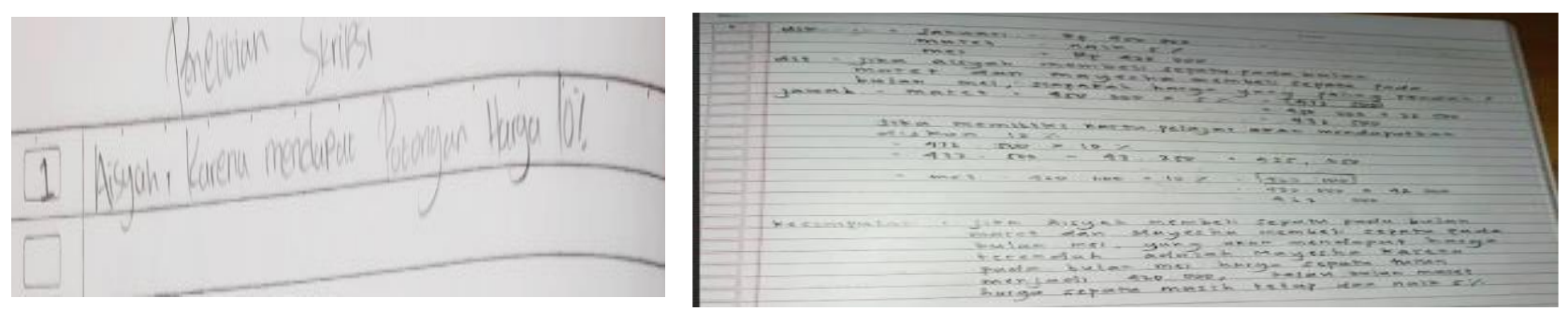

Figure 5. Answer results SR1 and SR 2.

In the low emotional group of siswa able to understand and interpret the problem into written and oral form, students are able to design, present and articulate the process of solving problems that have been done with arguments based on interpretation and action, but the subjects SR1 and SR 3 give the wrong answer, there is a mistake when the process of work, because there is little error in the solution then the conclusion of the problem solution is not appropriate. While the subject of SR2 has given the correct answer, there is a fallacy in interpreting mathematical results into a real-world context or not being careful in providing conclusions in solving problems. This is in line with the results of research conducted by Pangastuti (2014) that students with low levels of emotional intelligence the process of 
completion are done wrong, the sequence of wrong answers causes the conclusions given are also wrong.

\section{CONCLUSIONS}

Based on the results of the study can be concluded as follows: (a) High emotional intelligence. Have the ability of mathematical literacy that is moderate in the aspect of communication and high category aspects of designing problem solving strategies; (b) Emotional intelligence is low. Have the ability of mathematical literacy that is high in the aspect of communication and category while the aspect of designing problem-solving strategies; (c) Emotional intelligence is low. Have the ability of mathematical literacy that is moderate category on the aspect of communication and the category is the aspect of designing problem-solving strategies.

\section{REFERENCES}

Alwi,I. (2012). Kriteria Empirik Dalam Menentukan Ukuran Sampel. Jurnal Formatif, 2(2), 140-148.

Musyarrafah, Sofia. (2016). Perbedaan Kecerdasan Emosi Siswa Berdasarkan Program Kelas dan Jenis Kelamin di SMAN 4 Malang, SMAN 5 Malang, dan SMAN 8 Malang. Fakultas Psikologi. Malang: Universitas Islam Negeri Maulana Malik Ibrahim Malang.

OECD. (2013). Student Performance In Mathematics, Reading And Science, volume 1. Paris PISA OECD Publishing.

OECD. (2019). Assessment and Analytical Framework. Paris PISA OECD Publishing.

Pangastuti, L., Johan, A. \& kurniasari, I (2014). Profil Kemampuuan Komunikasi Siswa SMP Di

Tinjau Dari Kecerdasan Emosional. Jurnal ilmiah pendidikan matematika, 3(2).

Uno, H.B. (2016). Orientasi Baru dalam Psikologi Pembelajaran. Jakarta: PT Bumi Aksara. Wiyono, A., Anggo, M., \& Kadir, K. (2019). Pengaruh Kecerdasan Emosional Terhadap Hasil Belajar Matematika Siswa Kelas VII SMP Negeri 9 Buru. Jurnal Penelitian Pendidikan Matematika, 6(2), 113.

Wulan, R. (2011). Mengasah Kecerdasan Pada Anak. Yogyakarta: Pustaka Belajar. 